\title{
How Does the Rule of Law Impact the FDI Attraction? A Panel Study on Chinese Municipal Governments (2013-2017) ${ }^{1}$
}

\author{
Chengyu Fu \\ Dept. of Political Science, Duke University
}

\section{INTRODUCTION}

Foreign Direct Investment (FDI) has long been seen as an essential factor contributing to economic growth (Asiedu, 2006). Promoting FDI, therefore, is a significant goal for most governments around the world. Previous research has pointed out that the rule of law, also known as "nomocracy," is among the determinants of a country's FDI attraction (Campos and Kinoshita, 2003; Dam, 2006): the rule of law refers to a situation in which "the laws are public knowledge, are clear in meaning, and apply equally to everyone" (Carothers, 1998), qualities that are beneficial for the improvement of nations' FDI inflows.

However, researches focusing on the relationship between nomocracy and FDI still need improvement: current papers lack a consistent set of indices that comprehensively measure the rule of law, the case of China (low nomocracy with high FDI) is understudied, the effect of the local governments' rule of law is under-examined, and few researchers have explored the possibility that nomocracy's marginal impact is determined by the economic condition.

This study, therefore, focuses on the impact of the rule of law on FDI attraction in Chinese cities from 2013 to 2017. I divide nomocracy into four aspects and measure their different effects on FDI inflows. Furthermore, I present credible evidence that economic backgrounds influence the rule of law's marginal effects. My research will address the issues mentioned above and provide reasonable conclusions that rule of law, both general measurements, and its sub-indicators, has a significant influence on FDI inflows, and their impacts are conditional on the cities' performance in economic development.

The paper is organized as follows. The second section addresses significant literature related to the existence of the authoritarian rule of law, its impact on economic development, and what questions are this paper trying to settle. The third part discusses the data and methods for this study, including a description of the data collection process, presenting basic summary statistics, and showing density graphs of variables. The fourth section shows the interaction graphs and the regression results of the rule of law and FDI attraction, demonstrating the significant interaction of economic moderators and the rule of law. I conduct both OLS and two-way fixed effect regressions to control the variance of time and location in my analysis. The fifth section examines the robustness of my analysis by checking outliners, autocorrelation, and heteroskedasticity problem. As for the missing values, I use the K-Nearest Neighbor algorithm for imputation to confirm the robustness of my estimation.

\footnotetext{
1 This version is revised based on the conference paper in the APSA Panel "Political Economy of China and Vietnam" on August 30, 2019.
} 
The last part concludes the paper and further discusses the limitations and applications of my research.

\section{A BRIEF LITERATURE REVIEW}

Researchers have found that dictators in Asia, Africa, and Latin America are adopting legal construction reforms, with the "rule of law" being claimed as the intended goal of these programs. As a result, the concept of the "rule of law" has come to the stage of authoritarian studies. However, this subject has long been treated as a component of liberal democracies (Scalia, 1989), and some researchers argue that the legal reforms are bringing rule by law, instead of the rule of law (Rajah, 2012) to states where the supremacy of laws is hardly guaranteed. Thus, the adoption of "the rule of law" reforms in authoritarian regimes is faced with several problems: first, do "the rule of law" reforms just amount to rule by law in authoritarian settings? Second, do dictators adopt the rule of law reforms for economic development purposes?

To address these essential questions, this part will analyze the previous literature not only on the authoritarian rule of law but also on general nomocracy studies. The review will first concentrate on the conceptual problems: what does the "rule of law" mean? Is it theoretically reasonable for authoritarian regimes to improve their rule of law? And, have legal construction reforms successfully brought any extent of the "rule of law" to dictatorships? Next, the paper will discuss the popular academic argument that the rule of law is expected to stimulate economic development, as is common in dictatorship. I will not only review the positions which draw their conclusions from global experience but will also consider the positions set forth in papers which are based on specific authoritarian cases. Finally, this review will summarize the unsettled issues in the research of the rule of law, especially in authoritarian settings, and its impact on economic development. I will discuss then the contribution of my research in answering these research questions.

\subsection{Authoritarian "Rule of Law" or "Rule by Law"?}

The rule of law, also known as "nomocracy,"2 generally refers to a situation in which "the laws are public knowledge, are clear in meaning, and apply equally to everyone" (Carothers, 1998). However, this is not a clear definition; failure to clearly identify the concept is due to the fact that the rule of law is an "essentially contestable concept," with both "descriptive and prescriptive" content. As a result, there is no consensus on what "rule of law" should consist of (Rosenfeld, 2000), and a variety of definitions exist in academia.

\subsubsection{Debates on Conceptions}

For clarification, it is first necessary to distinguish between "thick" and "thin" conceptions of the rule of law. A "thin" definition doesn't refer to rights, democracy, social equality, justice, or moral standards of laws; it merely considers the rule of law as a limited

\footnotetext{
${ }^{2}$ We use the two terms interchangeably as is common in academic writings of "rule of law."
} 
set of rules (Roseveare, 2013). On the contrary, a "thick" concept tends to link the rule of law to freedom or egalitarianism, and democracy, liberty or human rights are standard components of a "thick" definition (Trebilcock and Daniels, 2009).

The debates between the minimalist and comprehensive conceptions have achieved no consensus on which works better in the rule of law evaluations, but scholars agree that some principles should be included when defining the rule of law. One version of a wellestablished nomocratic standard is raised by Raz (1977). He lists six principal standards, including prospective, open, transparent, and relatively stable laws; clearly-defined lawmaking standards; judiciary independence; observed principles of natural justice; review powers of the courts; and the discretion of crime preventing agencies should not pervert the law. These items, similar to other generally accepted criteria, are commonly used for evaluating the rule of law. None of them mention the "thick" part of nomocracy, and thus we can conclude that a "thin" version of the rule of law is the better choice for related studies when we are not clarifying the content, but just referring to a general rule of law.

\subsubsection{Is the Authoritarian Rule of Law Possible?}

A preference for minimalist conceptions can be observed in most of the rule of law measurement projects. For instance, the United Nations and the World Justice Program (WJP) are both adopting a "thin" working definition of nomocracy (Annan, 2004; Agrast et al., 2013). As we have discussed before, a thin definition of the rule of law does not treat democracy as a mandatory component, and thus it doesn't rule out the possibility that nondemocracies can have some extent of the rule of law. It's true that this nomocracy may not be full scale. However, our analysis on the first debate of the "rule of law" still provides evidence that the rule of law can survive in authoritarian regimes. Few scholars have theoretically proved that it is possible for authoritarianism to co-exist with nomocracy, and that's what we first achieve in this review.

However, a second debate affects the likelihood of dictators promoting the rule of law: researchers and observers argue that rather than the real rule of law, what authoritarian nations promote is in fact rule by law (Roseveare, 2013). Under the former, we know that no one could be exempt from the laws: the constitution and regulations seek to ensure that the state functions in the public interest. Under the latter, however, the law is an instrument of government, and leadership is above the law (Schlaeppi and McCabe, 2008).

To explain in a legal perspective, "rule of law" requires consent ex-ante: before the legal transaction is set in motion (Rosenfeld, 2000). When parties in a contract know what to expect, and they nonetheless choose to breach the terms of the contract, then enforcement of such contracts is fair and consistent and is sufficient in respecting their autonomy (Roseveare, 2013). However, for "rule by law," consent from contractors is not mandatory; dictators can draft anything they prefer, public interest can be neglected, and people are forced to accept and follow these contracts.

It's true that "rule by law" still dominates some authoritarian regimes. Rajah (2012) and Whiting (2017) find that rule by law has a long and influential history in dictatorships, due to societal or colonial influences. In addition, the promotion of the "rule of law" is often 
accompanied by governments' requirements that no challenges to existing one-party institutions are allowed; thus many "rule by law" factors are not impacted. For instance, Peerenboom (2002) claims that human rights demands are not likely to be considered in legal reforms. What's worse, authoritarian regimes are generally bereft of any independent authority that would enforce contracts (Svolik, 2012), and thus consent is not a mandate for leaders' actions: in fact, even the statutory construction itself is a policy in which no ex-ante consent is evident. In this situation, the citizenry doesn't know what to expect from the rule of law reforms, nor do they have the power to negotiate. All they can do, as a result, is accept the conditions which are imposed upon them.

Therefore, we should admit that even if dictators claim they are promoting the "rule of law," rule by law still dominates, unless the regime is overturned.However, it's still possible, and even likely, for dictatorships to develop a certain level of nomocracy: in real life, an authoritarian regime can still accept the existence of the "rule of law" in fields with little political involvement. Ferejohn and Pasquino (2003) provide an explanation for this possible combination. They argue that the rule of law should not necessarily be wrapped up in the definition of democracy: at the institutional level, democracy and laws only interact in legislatures. Thus the rule of law can generally "take on a life of its own." Since dictators are concerned with nomocracy's spill-over effect on democratization, they may allow for the existence of nomocracy only in fields with no threat to dictators' power control; in fact, this pattern is evident in many real authoritarian regimes.

There are many cases in which dictatorship adopt "de-politicized" rule of law reforms. For instance, China's increasing the rule of law can be partially proved by the explosive growth of formal legislation, the training of legal professionals, and the expansion of the court system (Whiting, 2017). A program to promote legal consciousness has also been conducted, aiming at increasing the legal awareness of a majority of Chinese citizens (Fu and Cullen, 2008). With these efforts in the rule of law promotion, studies have observed an increased performance of authoritarian nations' nomocracy in legislation and judicial fairness (Lubman, 1999).

For a brief summary, first, when our focus is not on the exact definition of the rule of law, a "thin" conception of nomocracy is adequate for our analysis of the concept's implications, for example. Second, although authoritarianism has inherent conflicts with the rule of law, dictatorships are still open to nomocracy reforms unless they involve changes to political institutions. With the existence of legal constructions in authoritarian regimes, the subsequent problem is: why do dictators promote the rule of law rather than sticking to a more accessible "rule by law"? Economic incentive, in reality, is one of the most significant factors for dictators' consideration.

\subsection{Rule of Law and Economic Development}

Economic growth has long been seen as the critical element for dictators, especially those East Asian ones, to survive in democratization waves and to increase their voice in the international community. The legal determinants for East Asia economic growth have been 
discussed quite often (Campos and Nugent, 1999; Ginsburg, 2000; Li, 2003). One of the bestorganized literature about the linkage between the rule of law and economic development, however, lies outside the field of authoritarian studies. Haggard et al. (2008) systematically summarize the linkage between the rule of law components and economic development. Their main point is that two aspects of nomocracy, property rights protection, and contract enforcement, are regarded as the core stimuli for investment and trade. A higher level of the rule of law is commonly accompanied by a better performance in protecting property rights and enforcing business contracts. Moreover, in reality, international financial and aid agencies have established the rule of law promotion programs, consisting of property rights and contract enforcement protections, to stimulate economic growth and to reduce impoverishment.

Based on their comprehensive summary, this section will emphasize these two critical mechanisms, but we will also spare many efforts on authoritarian cases. In addition, other aspects of the rule of law, e.g., legal environment, are thought to be beneficial for economic growth, and we will address these institutions as well. Similarly, the uniqueness of dictatorships will be discussed.

\subsubsection{Protecting Property rights}

The role of property rights was not emphasized until its applications in economic history analysis (see, for example, North and Thomas 1973; North 1981) grounded on new institutional economics. Based on previous reviews including Barzel (1997)'s, property rights can be conceptualized as "social institutions that define the privileges individuals and other legal entities, such as firms, enjoy concerning a given allocation of resources" (Haggard, MacIntyre, and Tiede, 2008). Property rights are typically thought to constitute a "bundle" of more discrete rights that can be disaggregated in a variety of ways, most generally into rights of control and rights over income. The more well developed and secure are property rights, the higher incentives individuals have to invest (Haggard, MacIntyre, and Tiede, 2008).

There is a broader body of literature that explores the linkage between property rights protection and economic development. For instance, there are solid theoretical grounds for assuming that more secure property rights should encourage investment, higher levels of innovation and productivity, and growth (both at a local and national scale). There is also a strong theoretical argument for property rights being able to facilitate the use of the property as collateral for credit (Roseveare, 2013). What's more, Acemoglu and Johnson (2005) identify a statistically significant correlation between property rights and long-run economic growth and financial development, although critiques hold that it is unlikely to isolate the effects of property rights from other institutions adequately.

While these studies explain much about the international situation, whether such conclusions are convincing in authoritarianism is understudied. However, there are case studies that focus on certain types of dictatorships, and China, the primary role in "East Asian Miracle," receives most significant attention. Although China started its reforms in 1978, protection of private property was not formally written into constitution until 2004. As a result, in the absence of formal protection of private property, private entrepreneurs face risks 
of expropriation as well as discrimination; what's worse, private enterprises had difficulty in accessing external loans before 2004. After the private property protection terms were introduced, we can observe a boom in investment, and private companies, although still being discriminated to some extent, gradually get a better position in competing for external finance (Bai, Lu, and Tao, 2006). This case, as a result, explains how property protection in authoritarian institutions can help to the economic prosperity of that dictatorship, supplementing the general theoretical analysis mentioned above.

\subsubsection{Ensuring Contract enforcement}

Comparing with the influence of property rights protections, the capacity to contract is equally fundamental for economic development (Haggard, MacIntyre, and Tiede, 2008). It is true that some traditional trade can take place in the form of barter or exchange, and they can clear immediately. However, in reality, more complex transactions require the ability to make and receive promises about future actions, and contracts form as a result.

This contract formation is typical in financial transactions nowadays, which, from a legal point of view, are primary contracts. Thus, a guarantee of contract enforcement enables these primary contracts to take effect. Furthermore, Secure property rights and the capacity to contract over time and space also permit trade and a corresponding increase in the efficiency of resource allocation, including through the development of the financial system (Haggard, MacIntyre, and Tiede, 2008).

The impacts of enforcement have also been demonstrated by empirical studies, although papers concentrated on dictatorships' contract enforcement is rare. A recent systematic review considers the effects of improved contract enforcement on levels of investment. It finds evidence that more effective contract enforcement generally promotes higher levels of investment (Aboal, Noya, and Rius, 2014). A negative example is Argentina, which has slipped to its current position close to mid-range developing countries. Prados de la Escosura and Sanz-Villarroya (2009) employed a structural model and investigated that weak contract enforcement played a significant role in the origins of Argentina's unique experience of longrun decline.

Although the mechanisms have been studied much, there is still a problem of endogeneity. That is, contract enforcement and property rights might be endogenous to some antecedent political conditions, or at least the effects of property rights are conditional on other institutions (Haggard, MacIntyre, and Tiede, 2008). We will further discuss these problems in the fifth section.

\subsubsection{Other Mechanisms: Overall Rule of Law and Independent Judicial Systems}

Some researchers are interested in the overall impact of nomocracy, instead of a specific rule of law aspects, on economic development. As a result, empirical studies provide evidence on these positive linkages expected by theorists. Kaufmann, Kraay, and ZoidoLobaton (1999) find that a 1-point increase on the rule of law is correlated with a 2.5 to 4 times improvement in incomes per capita and infant mortality, and a 15 to 25 percent increase in literacy rates. In similar research, Rodrik, Subramanian, and Trebbi (2004) find a 
significant correlation between "institutional quality" and incomes per capita, while the protection of property rights and strength of the rule of law feature heavily in their institutional measurements. These studies provide evidence on the strong correlation between the rule of law and economic development, yet the causality direction is not clarified, which we will discuss in detail in the next section.

Furthermore, studies have found that a direct product of the rule of law, an independent judicial system, tends to impact on economic development positively. Moreover, since authoritarian regimes suffer from a lack of an independent judicial system, investors are more likely to appreciate the investment environment provided by the rule of law. For instance, World Bank surveys in Brazil and Argentina reveal that firms operating in regions with better performing judicial systems will enjoy greater access to credit (Ndao et al., 2004). This declining case further demonstrates the economic influence of independent judicial systems in dictatorships.

\subsection{Unsettled Questions Discussed in This Research}

In the sub-sections above I have addressed the two questions: why authoritarian "rule of law" is possible (or at least being pursued by dictators), and why do dictators adopt legal constructions in exchange of economic benefits. One specific research interest that can provide empirical evidence for such relationships is the study of the rule of law and FDI attraction. For one thing, FDI serves as one of the most important stimulants for economic growth globally, and countries like China has long been working on attracting a higher level of FDI to accumulate resources for industrial constructions and long-term economic development.

For another, the flow of foreign investment to authoritarian regimes are different from those domestic investments: they are controlled by citizens from other countries, less influenced by domestic politics, thus possess much more freedom in choosing the destination. And since dictatorships, in general, indicate higher investment uncertainty and weaker protections for individual rights, if investors do not want to give away the market of these authoritarian countries, it is natural for FDI to look for specific locations that have higher levels of the rule of law. Therefore, it is reasonable to assume that for all the FDI heading toward the dictatorships, the external investment would prefer cities that have better regulation and legal environment so that they feel a sense of being better protected.

Several studies have focused on the correlation between nomocracy and FDI in different settings. However, the relationship between them is still under debate due to several problems influencing the validity of these papers. First, the definition of the rule of law by Carothers (1998) and other researchers indicate that nomocracy has more than one aspect. However, though some studies evaluate the rule of law as a multi-dimensional index (Haggard and Tiede, 2011), they don't form their own measurement of these aspects. Instead, they borrow the indexes from other researchers and investigate their influence on economic development. But Haggard and Tiede (2011) don't combine them in one regression, thus failing to control the impact of the indexes' overlap (i.e., having the omitted variable bias). 
As a result, a consistent, feasible evaluation standard of various aspects of the rule of law is required for studying nomocracy's multi-dimensional influence. In fact, Peerenboom (2002) claims that a "thin theory" for nomocracy, in which some necessary threshold for the rule of law are contained, is a must for the discussion of the influence of the rule of law. Furthermore, Ohnesorge (2007)'s review provides a comprehensive rhetoric discussion of nomocracy both in the Anglo American tradition and the international renaissance of the rule of law. His research points to a definition, which consists of "transparent legislation, fair laws, predictable enforcement, and accountable governments" (World Bank, 2002). These four dimensions fully cover the definitions of researchers, including Carothers (1998), and are accepted by many studies for its transparent and measurable divisions of nomocracy, and should be comprehensively incorporated for further studies.

Second, recent research mainly treats nations as subjects (Asiedu, 2006; Campos and Kinoshita, 2003; Franck, 2006), and the effect of the local governments' rule of law is underexamined. Although some studies focus on enterprises' datasets (Wang, Xu, and Zhu, 2012), pitifully they rule out the existence of nomocracy in their models, thus provide limited evidence on the correlation of the rule of law and economic development at subnational units.

Third, few papers explored the possibility that nomocracy's marginal impact is determined by the economic condition of the research subjects, which I will analyze in detail later. Such idea comes from Kolstad and Wiig (2012), who consider the interaction of the "rule of law" and economic moderators (natural resources), although their focus is on the outward FDI of China. In addition, they measure nomocracy with governance indexes, which measures the performance of government functions instead of the "rule of law" I mention in this essay.

An essential part of their results is that they find Chinese outward FDI will be attracted to countries with a combination of abundant natural resources and weak institutions. This conclusion indicates that excellent performance in political indicators doesn't guarantee higher FDI inflows, and the marginal effects of the "rule of law" rely on the economic background of nations. Therefore, I may hypothesize that similar interactions exist for Chinese FDI inflows.

Lastly, the case of China, where nomocracy is low but FDI is high, is understudied. Although Peerenboom (2002) and Wang (2014) focus on the development of the "rule of law" in China, the first literature provides few empirical pieces of evidence on the linkage of economic growth and nomocracy, which lowers the convincingness of the research validity. The latter one is good at statistical analysis, yet he defines the rule of law as legal activities, not covering other aspects (e.g., the governments' functioning in accordance with laws) of nomocracy.

Furthermore, for Wang (2014), he considers the causality from FDI to corruption in judicial reforms. However, first, corruption is just one part of the rule of law: it involves more with the economic transactions instead of political institutions. However, the rule of law reforms in China is much more comprehensive: it, in reality, relates more with the political reforms, like reducing the number of procedures for setting up businesses or entering a 
specific industry. These transformations are thus government-oriented instead of judicialbased, and focusing on court corruption would be narrowly scoped.

In addition, Wang (2014) concentrates on the effect of FDI on individual perceptions, which are not manipulatable. Consequently, his book would argue that socio-economic settings will impact individuals' actions rather than citizens' attitudes influence government behavior (it is unlikely to take place in contemporary China with a lack of supervision and voting). It is possible that market participants affect the behavior (or political choices) of governments, but this reversal causality is unlikely to take place in my study. In other words, if researchers treat local governments as subjects, these units are not reforming the rule of law purely for higher FDI attractions; instead, what they are conducting conforms with the requirements from the central government.

As is indicated by Outline of the Implementation of Constructing a Rule of Law Government, the aim of improving nomocracy is to "fulfill the goal of completing the building of a moderately prosperous society in all respects by 2020" (Xinhua News Agency, 2015), which is the set of goals set up by Deng Xiaoping around the beginning of 1980s. Therefore, the difference of local government with regard to the rule of law reforms, as a result, lies mostly in the extent of reforms rather than the motivation of the actions. It is thus reasonable to assume that foreign capitals are not primary reasons for governments to work hard in the rule of law reforms; instead, the causality is more likely to derive from local administration reforms in nomocracy to the economic development, which is the main logic of my essay.

This paper, consequently, will try to address all these four problems in previous literature. I will focus on the influence of several main sub-indicators of the rule of law on FDI. By utilizing city-level dataset, the research reveals the pattern in which local governments' rule of law reforms impact on economic performance like FDI attraction. Besides, I will try to provide evidence on the rationality of using interactions between nomocracy and economic indicators to estimate how they influence the marginal effect of nomocracy. And, above all, my research will concentrate on the causality that the local rule of law reforms will lead to changes in foreign direct investment.

\section{DATASET AND METHODOLOGY}

This section will discuss the process to select variables and collect dataset. Some basic summary statistics and density graphs will also be presented.

\subsection{The Independent Variables}

First, I will focus on the collection of independent variables, the sub-indicators, and the overall estimation of the rule of law. To comprehensively measure the four dimensions of nomocracy mentioned above in Chinese local governments, I derive indicators from the Annual Assessment Report on China's Law-Based Government, conducted by the School of Law-Base Government in China University of Political Science and Law. It assesses the 
annual rule of law performance of 100 cities from 2013 to 2017 from nine secondary-indexes. The values of these indexes are based on a combination of expert-evaluation (subjective performance assessment, including overall policy transparency) and field-investigator judgment (objective standards, e.g., the availability of governments' responses to delegates of the local People's Congress). I use this dataset because it is one of the most comprehensive (and neutral) evaluations of Chinese cities' local-level performance with respect to the city governments' rule of law.

Furthermore, excluding the four provincial-level municipalities (Beijing, Shanghai, Tianjin, and Chongqing), the remaining 96 cities come from all the other 27 provinces/autonomous regions in mainland China. As a result, these cities will be a valid representation of the municipal governments' performance around China. Table 1 presents the distribution of city locations. I can find that all the 7 geographic regions in China are covered. Although eastern cities are most common, the research makes sure that every region has at least 6 cases to be evaluated. Therefore, this study offers a relatively comprehensive assessment of the Chinese cities' rule of law performance for the last five years.

Some may question my focus on relatively bigger cities in China, ignoring the mediumor small-sized municipals. For one thing, the sample of our study is limited by the scope of the original evaluation by China University of Political Science and Law: it is much more difficult for the research institutes to get access to the resources and situations of the smaller cities (e.g., some cities locate at the boundary of countries and is hard to estimate by sending out interviewers). For another, the FDI dataset is hardly available for the smaller sized cities, since many of these regions have a minimal size of foreign investment and they tend not to report to the public. In this case, these small cities are likely to be treated as missing value cases even if they are included in the survey, and their low amount of FDI may also bias the regression results.

\begin{tabular}{rr} 
Table 1: Region Distribution \\
\cline { 2 - 2 } & V1 \\
\hline east & 32 \\
middle & 17 \\
north & 10 \\
northeast & 10 \\
northwest & 6 \\
south & 12 \\
southwest & 9 \\
\hline
\end{tabular}

In addition, although all the nine indicators are related to the rule of law, not all of them are significant for my consideration of FDI inflows. For instance, one of the sub-indicator measures the leaders' emphasis on promoting the rule of law. However, whether leadership cares about nomocracy relates little to FDI, and thus, it is not necessary to control that variable in regression analysis. Therefore, based on the theories I discussed in the first section, I take four dimensions - policy transparency, public satisfaction, external supervision, and law enforcement - as the sub-indicators of nomocracy in my study. 
Furthermore, it's still necessary (and theoretically reasonable) to have a single indicator to reflect the nomocracy of all cities. It will benefit my analysis of the rule of law's overall influence on FDI inflows. Therefore, I utilize the principal component analysis to aggregate the four dimensions into one variable. Figure 1 presents the scree plot for parallel analysis, and I can find that first, just one eigenvalue exceeds one, and second, it is the only point in which the eigenvalue of the actual data is higher than that of the simulated data. Both findings prove that one principal component will adequately represent the four indicators and reflect the overall rule of law.

Figure 1: Scree plot For Parallel Analysis

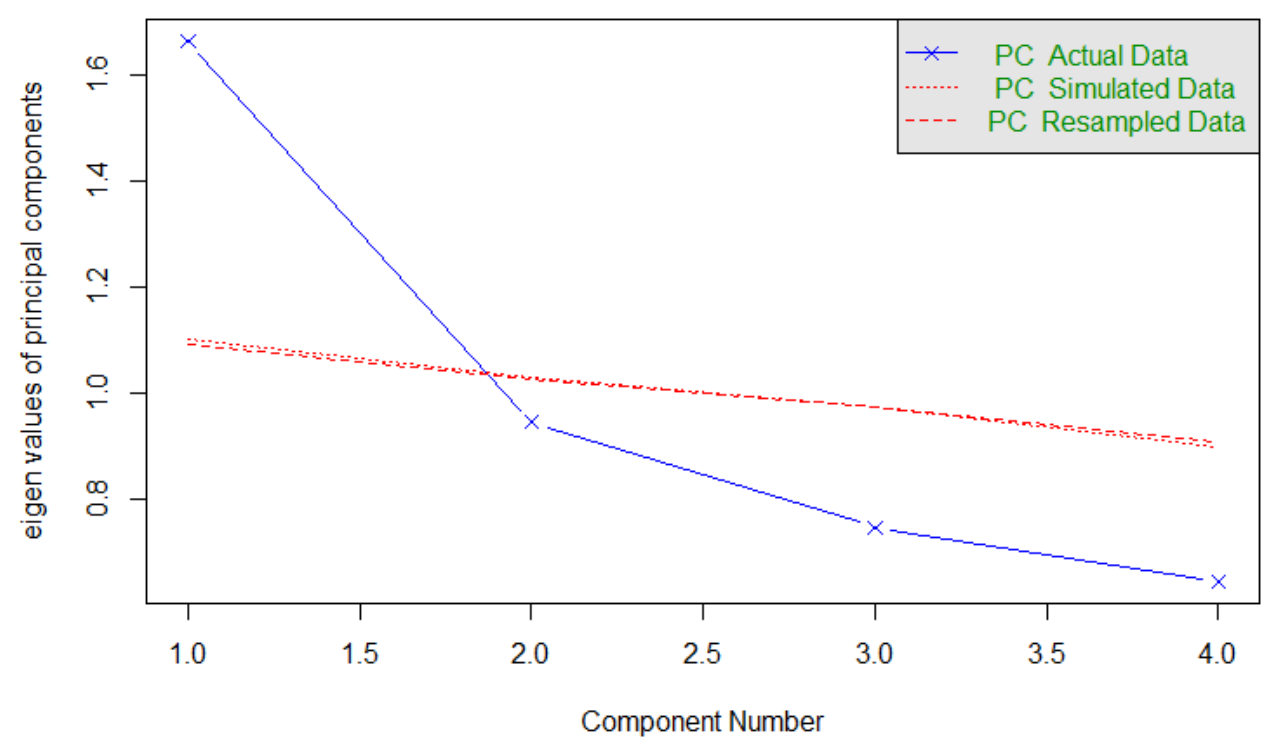

As a result, I try to draw one principal component from the four indicators, and the standardized loading matrix is presented in Table 2. From the correlation coefficients in the first column, I can find that all the principal component is highly related to all the variables. The second column presents the proportions of variances explained by the principal component, and I can see that this component can represent a large section of all variables. However, the unexplained variances, as indicated in the third column, is quite high. On the other hand, the overall explained proportion is $42 \%$, which doesn't exceed $50 \%$. Therefore, concluding from all these statistics, the principal component is useful in explaining the general nomocracy, yet its coverage is not adequate; thus, models based on sub-indicators should be discussed in my regression analysis.

Table 2: Loading Matrix of Principal Component

\begin{tabular}{lrrr} 
& PC1 & h2 & u2 \\
enforcement & 0.68 & 0.47 & 0.53 \\
openness & 0.63 & 0.40 & 0.60 \\
supervision & 0.70 & 0.50 & 0.50 \\
satisfaction & 0.55 & 0.30 & 0.70 \\
& & & \\
\multicolumn{1}{c}{ PC1 } & \\
SS 1oadings & 1.66 & \\
Proportion Var & 0.42
\end{tabular}




\subsection{Dependent and Control Variables}

Based on the independent variable collected above, I construct a dataset of 96 Chinese municipal governments by inserting other variables. For the dependent variables, I collected the FDI utilized by cities of these five years. Most of these numbers are available in the Annual Statistical Reports Economic and Social Indicators published by the Statistic Bureau of each city; for those unrevealed ones, I refer to the annual government reports, the official news, and the Statistical Yearbook of Chinese Cities.

As for the control variables, I go through pre-existing literature and find that some other indicators are convincingly contributing to FDI inflows. Dunning (2008) first points out the location advantages of FDI recipients in 1993. He finds that the advantages derived from the supply side (labor costs, corporate taxation), the demand side (market size and growth) and the political and social infrastructure. Wang, Xu, and Zhu (2012) further summarize three factors that significantly influence FDI: good infrastructure, a large market, and ethnic linkage to foreign investors. The influences of factors are demonstrated in various studies (Asiedu, 2006; Bajpai and Sachs, 2000; Hewko, 2002; Jensen, 2003; Kinoshita and Campos, 2003; Pournarakis and Varsakelis, 2004; Zheng, 2016).

As a result, to figure out the real influence of the rule of law and reduce the omitted variable bias, my analysis should control the impacts of these variables. I choose GDP per capita, population, and GDP growth rates from annual municipal statistical reports to represent the effects of market size, labor availability, and potential growth - all of them are significant determinants for FDI inflows. Additionally, it should be noted that I use the nominal GDP growth percentages because the government-reported growth has a severe problem of correctness: during the data cleaning process, I find several cases in which the nominal GDP decreases and the currency inflates, but the reported growth is positive. I also collect information on the existence of high-speed railway stations and airports of the surveyed cities. Since transportation conditions are generally expected to influence the economic development, adding these indicators can control their impact; also, both binary ( 0 and 1) variables can help to estimate the infrastructure level of the regions.

I am aware that macro-level observational datasets are faced with many problems, and I try to cope with some of them here. The independent and control variables are collected from reports a year earlier than the dependent variable to avoid causality inversion. Both the dependent and control variables are expressed in their logarithmic forms to adjust their distributions to normal ones. The only exception is GDP growth rate, because it is already a percentage variable, and since the dependent variable is estimated by its logarithmic form, the coefficients on the GDP growth will reflect the percentage change of the FDI inflows when the GDP growth rate changes 1 percent.

The density graphs of these economic and social indicators are presented in Figure 2. Generally speaking, all the five indicators follow normal distributions, after the mathematical transformations are made. Only the GDP per capita shows a non-normal, bi-modal density graph. However, this doesn't mean that Gauss-Markov Assumption 4 and 5 (and the classical 
linear assumption 6) are violated: my focus should be the residual term, not the distribution of control variables. Therefore, I will draw the residual plot and Q-Q plot in the fifth section.
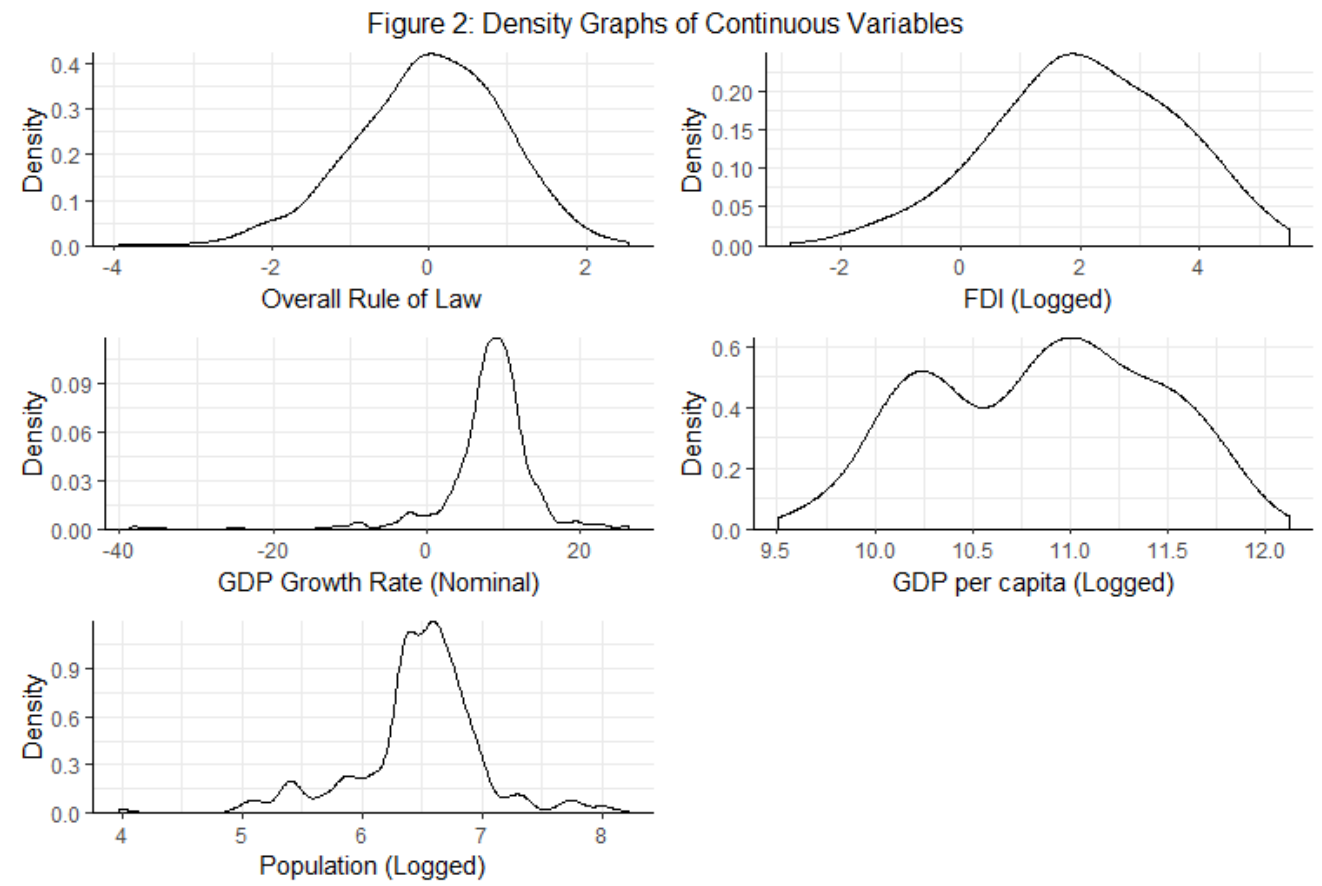

To summarize the basic statistics, I draw Table 3 in which the means, medians, ranges, standard deviations, skewness, and kurtosis of most variables are presented as reference. I can find by the skewness that the variables are distributed symmetrically, and their kurtosis values are generally around 0 (normal distribution's value). Both demonstrate the fact that most indicators in my research approximately follow the normal distribution.

Table 3: Basic Statistics of Variables

\begin{tabular}{rrrrrrrrrr}
\multicolumn{10}{c}{ Table 3: Basic Statistics of Variables } \\
\hline & $\mathrm{n}$ & mean & $\mathrm{sd}$ & median & min & max & skew & kurtosis & se \\
\hline Law Enforcement & 480.00 & 54.76 & 13.19 & 55.00 & 12.50 & 89.17 & -0.21 & -0.20 & 0.60 \\
Policy Transparency & 480.00 & 74.82 & 13.35 & 76.25 & 24.17 & 100.00 & -0.73 & 0.65 & 0.61 \\
External Supervision & 480.00 & 68.51 & 10.69 & 69.04 & 6.00 & 92.95 & -0.80 & 2.21 & 0.49 \\
Public Satisfaction & 480.00 & 63.21 & 6.73 & 63.16 & 42.69 & 85.02 & 0.03 & 0.38 & 0.31 \\
GDP Growth Rate & 478.00 & 8.04 & 6.30 & 8.65 & -38.66 & 26.36 & -2.88 & 17.74 & 0.29 \\
Airport & 480.00 & 0.69 & 0.46 & 1.00 & 0.00 & 1.00 & -0.81 & -1.35 & 0.02 \\
High-speed Railway & 480.00 & 0.68 & 0.47 & 1.00 & 0.00 & 1.00 & -0.76 & -1.43 & 0.02 \\
FDI (logged) & 457.00 & 1.91 & 1.47 & 2.00 & -2.85 & 4.94 & -0.35 & -0.29 & 0.07 \\
GDP Per Capita (logged) & 476.00 & 10.83 & 0.58 & 10.89 & 9.51 & 12.12 & -0.04 & -0.92 & 0.03 \\
Population (logged) & 475.00 & 6.42 & 0.47 & 6.51 & 3.97 & 7.38 & -1.45 & 3.38 & 0.02 \\
Rule of Law & 480.00 & -0.05 & 0.97 & -0.03 & -3.95 & 2.54 & -0.43 & 0.49 & 0.04 \\
\hline
\end{tabular}

Table 4: Airports

\begin{tabular}{llllll}
\hline Type & 2013 & 2014 & 2015 & 2016 & 2017 \\
\hline No & 31 & 31 & 30 & 30 & 28 \\
Yes & 65 & 65 & 66 & 66 & 68 \\
\hline
\end{tabular}


Table 5: High-speed Railway Stations

\begin{tabular}{llllll}
\hline Type & 2013 & 2014 & 2015 & 2016 & 2017 \\
\hline No & 44 & 38 & 28 & 24 & 21 \\
Yes & 52 & 58 & 68 & 72 & 75 \\
\hline
\end{tabular}

It's true that these two values of GDP growth rate deviate far from 0 . The primary reason is that, with the influence of some extreme cases in which the nominal GDP growth is highly negative, the curve leans leftward. Moreover, the leptokurtosis of GDP growth rate is due to the reality that cities in China are still experiencing an era of rapid economic development, and it increases the density values by "accumulating" the cities in a range of higher growth percentages.

Table 4 and Table 5 show the numbers of airports and high-speed railway stations, respectively, in these 96 cities. I can find that the percentages of both transportation means are increasing from 2013. And the railway station proportion has been booming, reflecting the rapid increase of high-speed railway system in China. Therefore, these indicators can serve as a useful measurement of the cities' infrastructure level.

One thing to add is that the missing value problem is unavoidable since some cities (e.g., Lasa, the capital of Tibet) tend not to reveal their statistics. As a result, these missing entries will increase the omitted variable bias, and I will deal with them in the Robustness section.

\subsection{Methodology}

First, I will utilize the "interflex" package developed by Hainmueller, Mummolo, and Xu (2018) to demonstrate the importance of the interplay between the rule of law and economic conditions. I will draw interaction graphs, check the statistical significance of interaction terms, and refer to the procedures in the paper to make sure the assumptions are met, and conclusions are correctly drawn.

Based on the visualizations and analysis, I will run regressions and add significant interaction terms to them. Both OLS and two-way fixed effect models are included: by comparing OLS results with fixed effect regressions controlling the variances of time and locations, a robust estimation of the coefficients will be provided. On the other hand, I will not only evaluate the marginal effect of the overall rule of law but also discuss the four subindicators' influence on FDI inflows by presenting separate models. Similarly, both OLS and fixed-effect models for sub-indicators will be included, and the significant interactions of GDP growth rate/GDP per capita with sub-factors will be added.

In sum, in the Results section, I will first present the interaction graphs drawn by "interflex" package. Then the results of both OLS and two-way fixed effect regressions will be shown, in which the influence of the overall rule of law and sub-indicators will be separately presented in different tables.

\section{RESULTS: INTERACTION AND REGRESSIONS}


Based on the theories and methodology discussed in the first two sections, in this part, I will present the proof of interaction effects and explain the OLS/two-way fixed effect regression results.

\subsection{Interaction Terms}

I first prove that the interactions between the rule of law and the economic indicators have a significant impact on the marginal effects of the nomocracy. In the Introductory section, I have argued that prosperity and growth rate are two moderators that may have an influence on the marginal effects of nomocracy. To test such a hypothesis, I show the graphs and tests provided by the "interflex" package.

Figure 3 presents the scatter plots of FDI on the overall rule of law, categorized by low/medium/high levels of GDP growth rate. Three regression lines are drawn for different plots, and smooth lines calculated by the "loess" method are also added. From this graph, I can find that first, the numbers of data points are adequate to calculate OLS models of different ranges. Second, the slopes of the regression lines differ with each other, indicating that GDP growth rate is likely to impact on the marginal influence of nomocracy. And third, the regression lines are close to the smooth lines given by the "loess" method. Thus linear models are efficient to estimate the rule of law's effects.

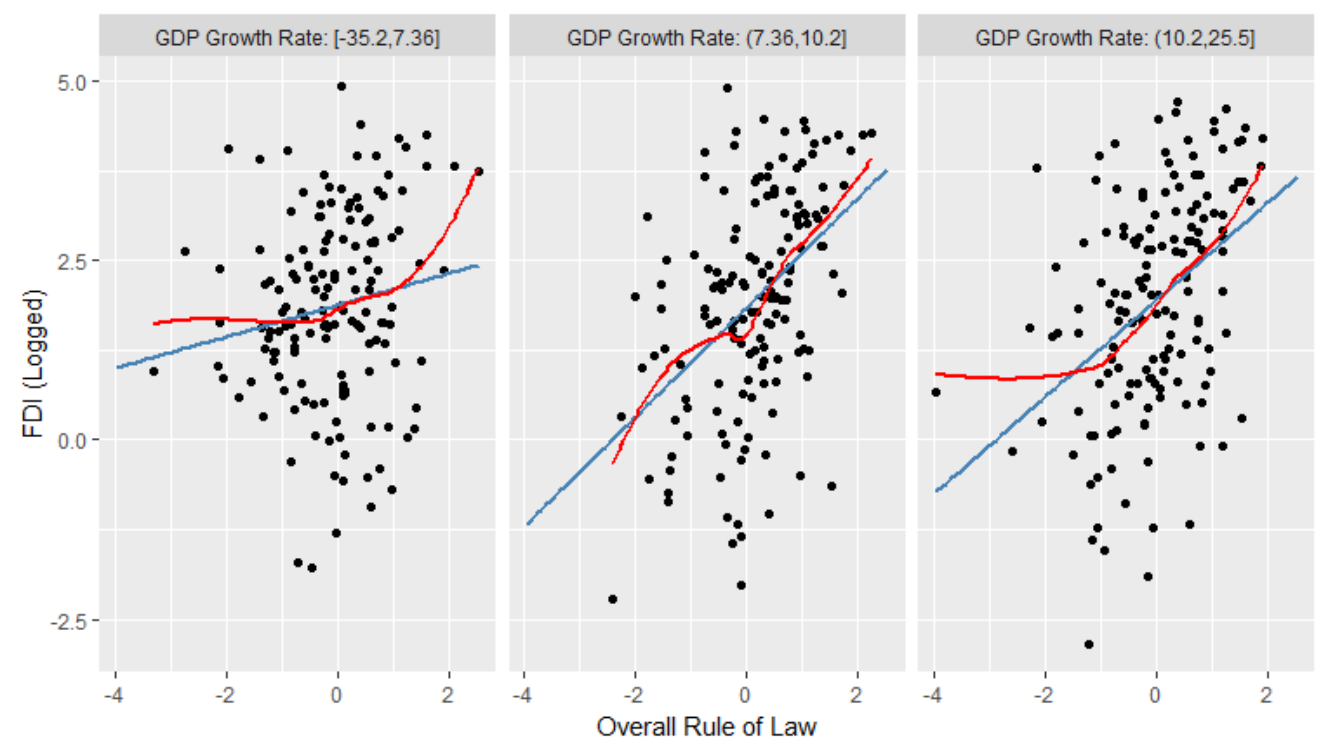

Figure 3: Scatter Plot, Categorized by GDP Growth Rate

With these conclusions, I get Figure 4, in which the marginal influence of the rule of law, moderated by GDP growth, is shown by one model. This interaction is estimated under twoway fixed-effect models to control the variances of time and locations. From this graph, I can conclude that GDP growth rate has a positive impact on the marginal effect of nomocracy. Besides, the graph includes three bins, representing the confidence intervals of the coefficients on different quantile points, and I can observe a significant difference between 
the first and third bins. Statistical tests also demonstrate the arguments drawn from the graph: the p-value of the student T-test between the first and third group is 0.0006, significant at a 0.01 level.

Figure 4: Interaction of GDP Growth Rate and Rule of Law (Two-way Fixed Effect)

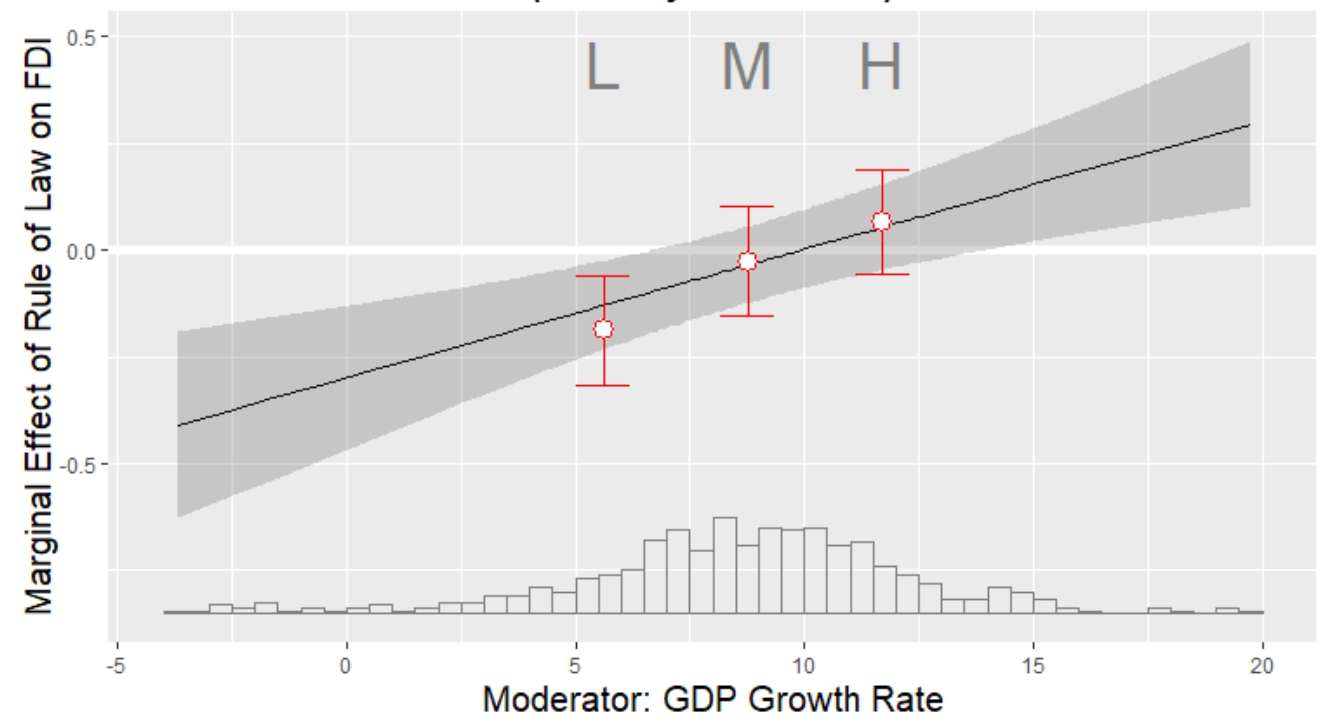

In addition, Hainmueller, Mummolo, and Xu (2018) claim that a Wald test is necessary to see whether the linear interaction assumption (the effect of the independent variable on outcomes linearly change with the moderator at a constant rate) is violated. Since the test value of this model is 0.5459 , I cannot reject the null hypothesis, which means I should include a linear interaction term in the regression below. In sum, the analysis of Figure 3 and 4 provide us with enough evidence to say that the interaction between GDP growth and the overall rule of law is significant.

I have examined the interaction of GDP per capita with overall rule of law, but no significant difference between groups is detected. Therefore, I now turn to the interplay between the rule of law dimensions and economic indicators. I have tested all possible interaction effects, and find that two influences are significant and pass the statistical tests: GDP growth rate has a positive impact on the marginal effect of public satisfaction, and GDP per capita negatively affect the marginal influence of policy transparency. Figure 5 and Figure 6 present these influences, respectively. The smallest p-values of the t-tests between the bins are 0.0102 and 0.0122 for each graph (i.e., comparing the first and third bins in Figure 5, and contrasting first and second bins in Figure 6), both significant at a 0.05 level. So, it's reasonable to include these two interactions in regression models. 


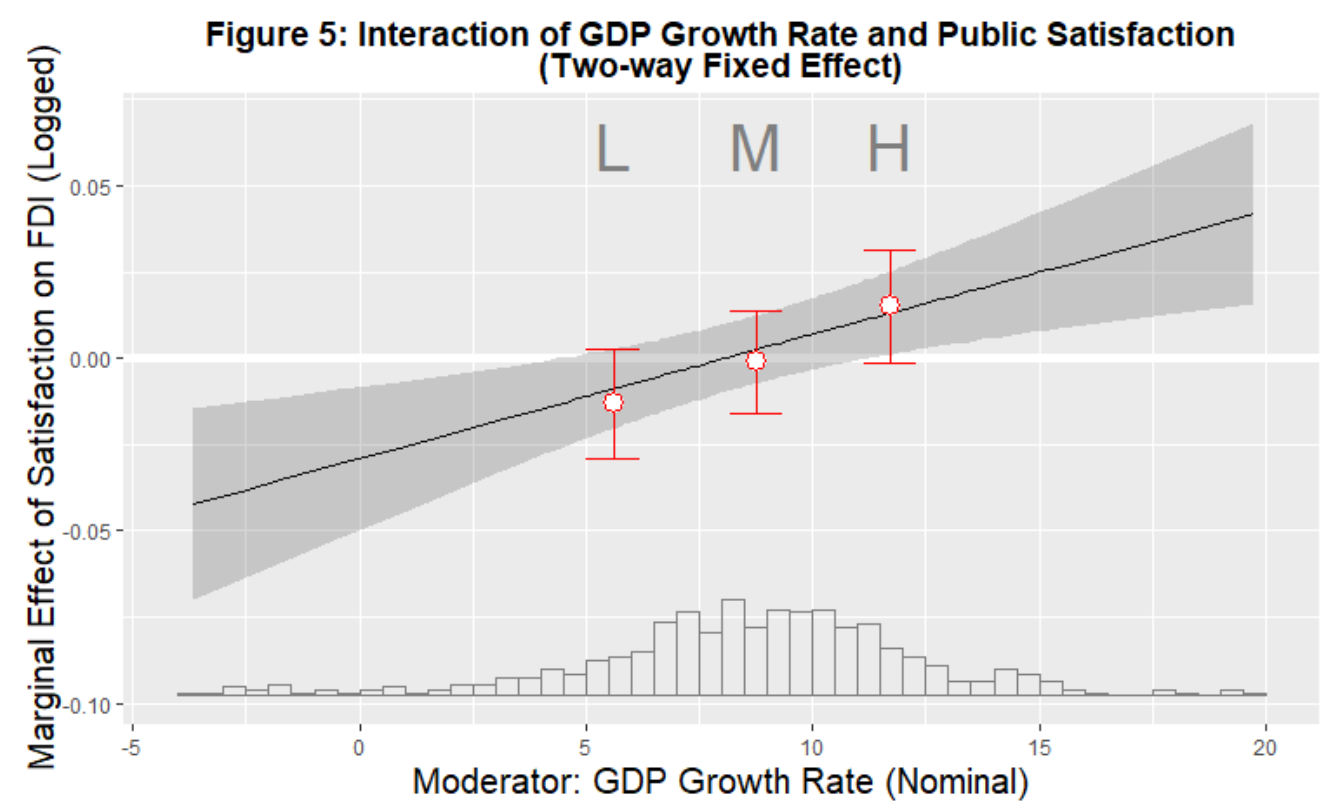

Figure 6: Interaction of GDP Per Capita and Policy Transparency (Two-way Fixed Effect)

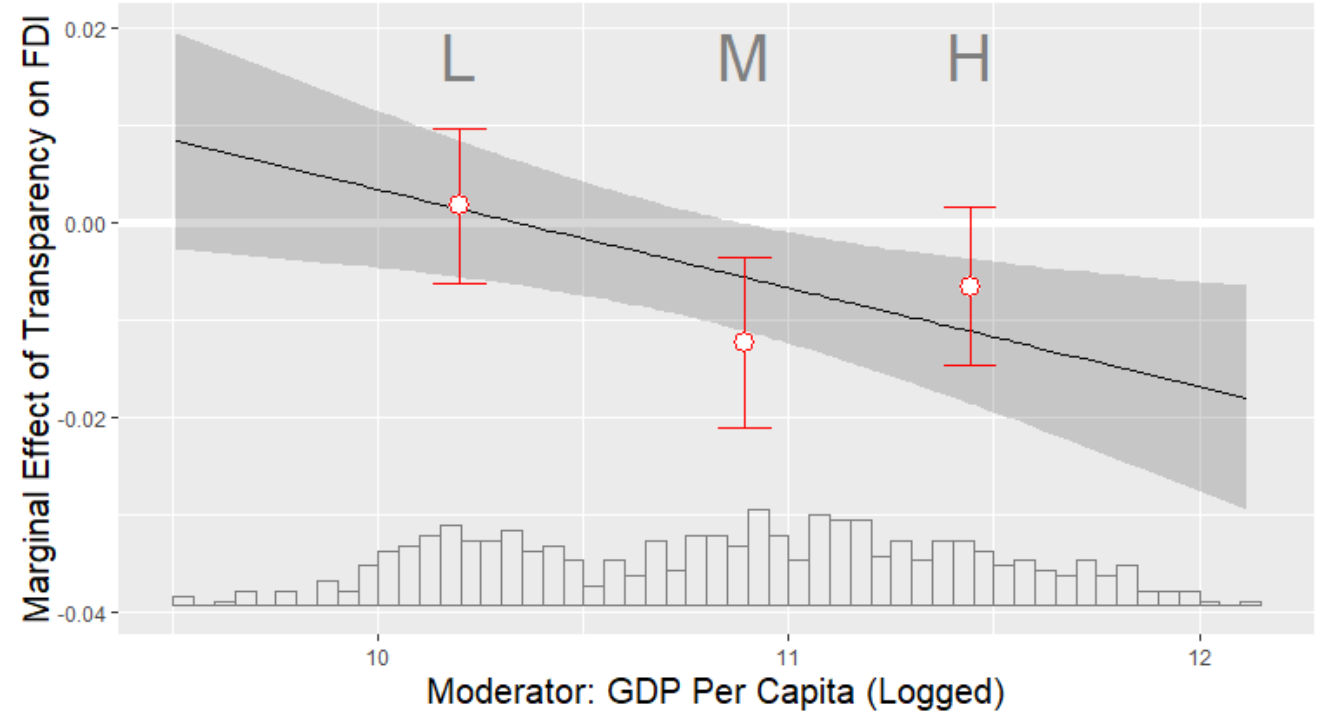

\subsection{Regression Results}

Here I will first present the regression models with the overall nomocracy as the independent variable. Table 6 and Table 7 show the OLS and two-way fixed effect results, respectively. Model 1 of each table presents the bivariate regression result, model 2 puts in the quadric form of the independent variable, and model 3 adds the interaction term. Model 4 considers the regression with independent variable, its interaction with economic moderators, and all other control variables. 
Table 6: FDI on Overall Rule of Law and Control Variables (OLS)

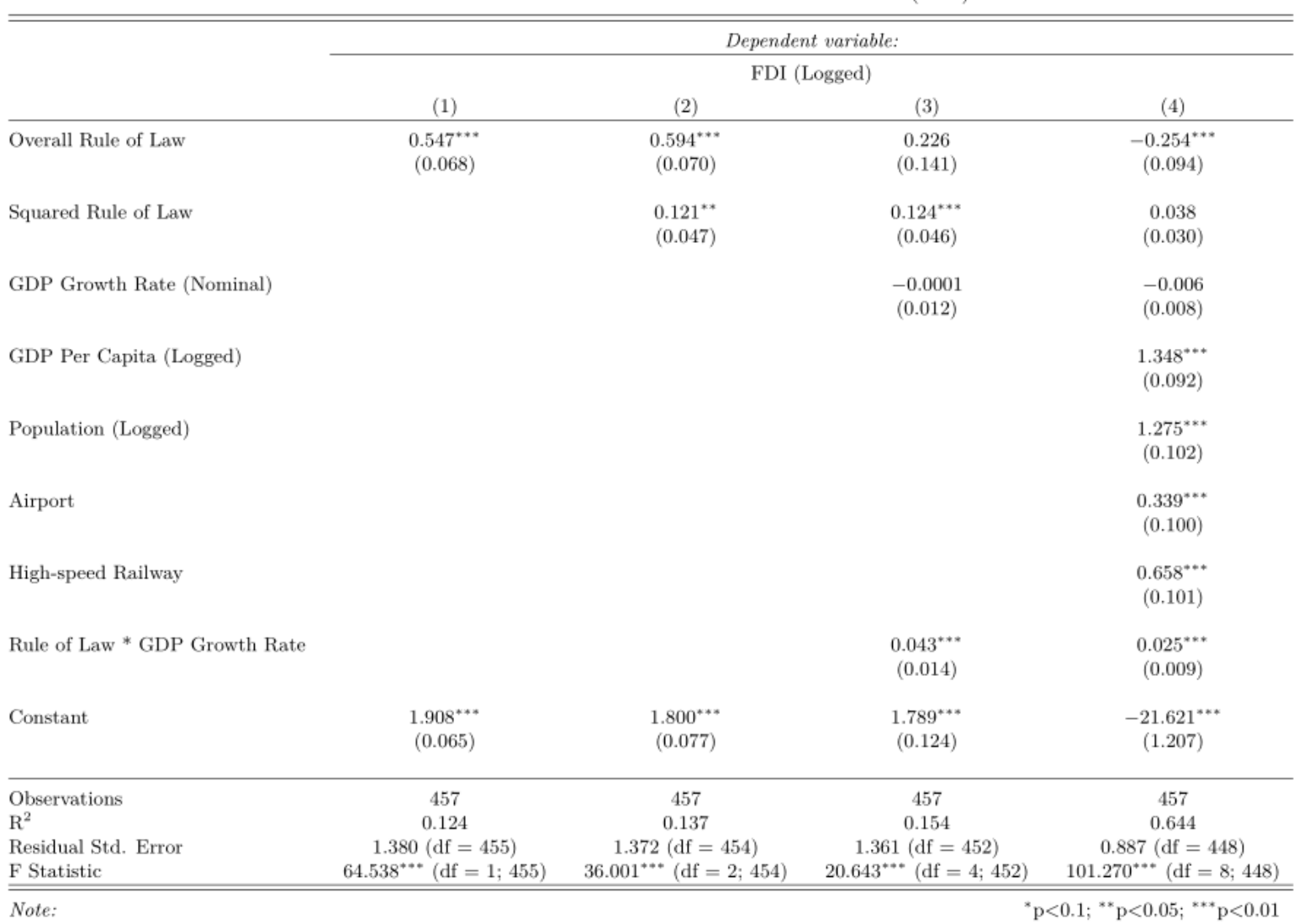

Table 7: FDI on Overall Rule of Law and Control Variables (Two-way Fixed Effect)

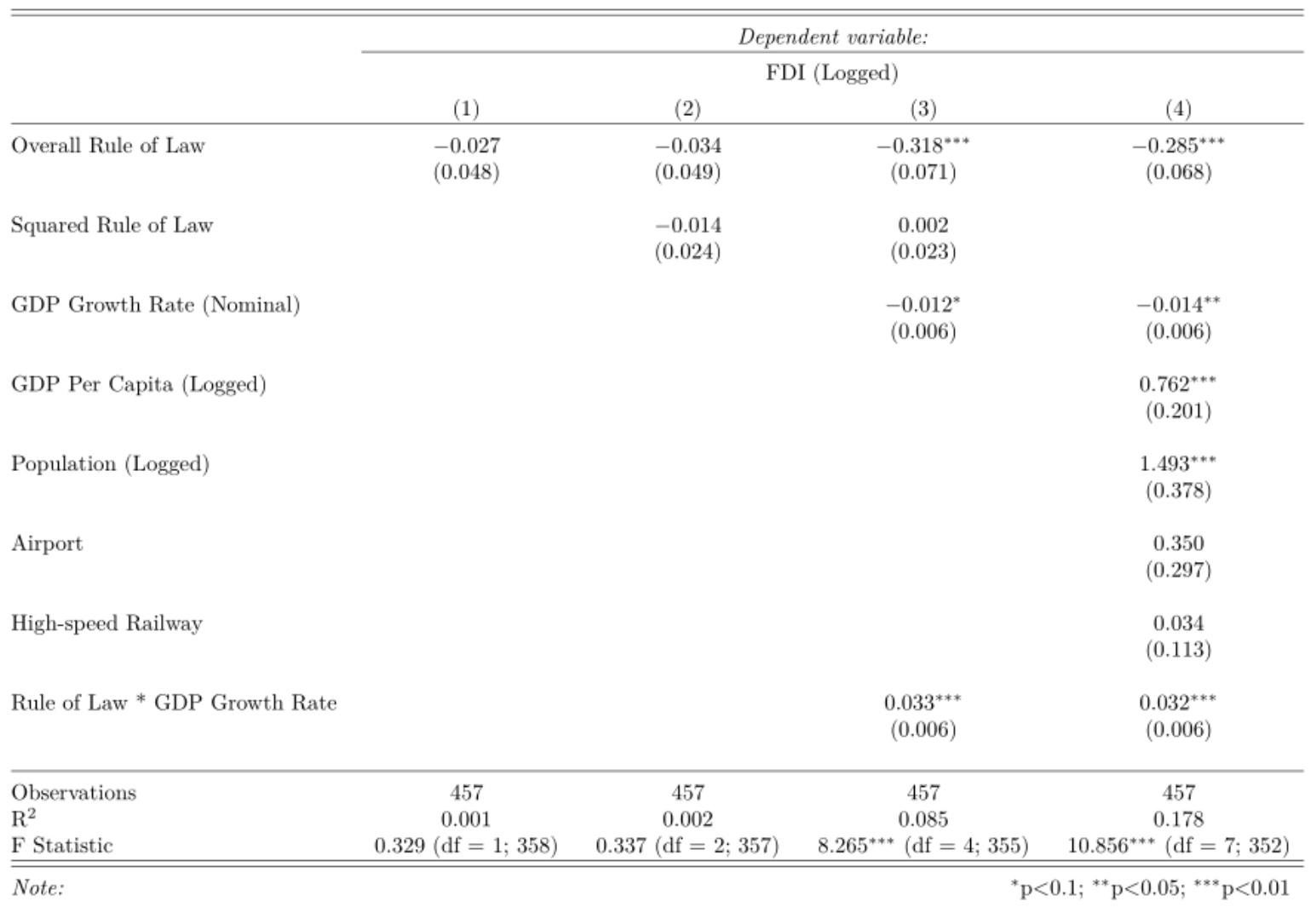


From Table 6 and 7, I can draw some core conclusions: first, I observe no significant quadric form of the rule of law's influence after controlling the covariates, and thus I don't include it in the fixed effect models. Second, bivariate regressions indicate that rule of law has significant influences, but it's too simple: In model 3, where the interactions are added, the margins of the independent indicator's influence change significantly. Third, the impact of the interaction term is proven to be significant by the graphs before, and my regressions further illustrate it.

Fourth, and the most important, the rule of law and its interaction with GDP growth rate is statistically significant, even after controlling time and location variances. The substitutive term has a negative coefficient, while the interaction term has a positive one. These statistics indicate that the rule of law tends to negatively impact the cities' FDI inflows if they are developing slowly, and positively influence the FDI attraction for fast-growing cities. This dual effect has not been discussed in previous literature.

Now I turn to Table 8 and Table 9, in which the influences of various aspects of the rule of law are considered. Similar to the previous analysis, the first table presents the OLS results while the second shows the two-way fixed effect regressions. Model 1 of each table considers only the four indicators of nomocracy, model 2 and 3 put in the two interaction terms, public satisfaction with GDP growth rate and policy transparency with GDP per capita, respectively. Lastly, all the indicators, control variables, and interaction terms are included in the fourth model. 
Table 8: FDI on Rule of Law Indicators and Control Variables (OLS)

\begin{tabular}{|c|c|c|c|c|}
\hline & \multicolumn{4}{|c|}{ Dependent variable: } \\
\hline & \multicolumn{4}{|c|}{ FDI (Logged) } \\
\hline & (1) & (2) & (3) & $(4)$ \\
\hline Law Enforcement & $\begin{array}{c}0.024^{* * *} \\
(0.005)\end{array}$ & & & $\begin{array}{c}0.001 \\
(0.004)\end{array}$ \\
\hline Policy Transparency & $\begin{array}{c}0.016^{* * x} \\
(0.005)\end{array}$ & & $\begin{array}{l}-0.058 \\
(0.074)\end{array}$ & $\begin{array}{c}0.011 \\
(0.061)\end{array}$ \\
\hline Public Satisfaction & $\begin{array}{c}0.006 \\
(0.010)\end{array}$ & $\begin{array}{c}0.012 \\
(0.020)\end{array}$ & & $\begin{array}{l}-0.020 \\
(0.013)\end{array}$ \\
\hline External Supervision & $\begin{array}{c}0.023^{* * *} \\
(0.007)\end{array}$ & & & $\begin{array}{c}-0.011^{* *} \\
(0.005)\end{array}$ \\
\hline GDP Growth Rate (Nominal) & & $\begin{array}{l}-0.098 \\
(0.128)\end{array}$ & & $\begin{array}{l}-0.118 \\
(0.080)\end{array}$ \\
\hline Public Satisfaction * GDP Growth Rate & & $\begin{array}{c}0.002 \\
(0.002)\end{array}$ & & $\begin{array}{c}0.002 \\
(0.001)\end{array}$ \\
\hline GDP Per Capita (Logged) & & & $\begin{array}{l}1.178^{* *} \\
(0.529)\end{array}$ & $\begin{array}{c}1.433^{* * *} \\
(0.446)\end{array}$ \\
\hline Population (Logged) & & & & $\begin{array}{c}1.284^{* * *} \\
(0.104)\end{array}$ \\
\hline Airport & & & & $\begin{array}{c}0.336^{* * *} \\
(0.101)\end{array}$ \\
\hline High-speed Railway & & & & $\begin{array}{c}0.684^{* * *} \\
(0.103)\end{array}$ \\
\hline Policy Transparency * GDP Per Capita & & & $\begin{array}{c}0.006 \\
(0.007)\end{array}$ & $\begin{array}{l}-0.001 \\
(0.006)\end{array}$ \\
\hline Constant & $\begin{array}{c}-2.586^{* * *} \\
(0.734)\end{array}$ & $\begin{array}{c}1.133 \\
(1.252)\end{array}$ & $\begin{array}{c}-11.580^{* *} \\
(5.675)\end{array}$ & $\begin{array}{c}-20.880^{* * *} \\
(5.023)\end{array}$ \\
\hline Observations & 457 & 457 & 457 & 457 \\
\hline $\mathrm{R}^{2}$ & 0.134 & 0.015 & 0.438 & 0.643 \\
\hline Residual Std. Error & $1.377(\mathrm{df}=452)$ & $1.467(\mathrm{df}=453)$ & $1.108(\mathrm{df}=453)$ & $0.891(\mathrm{df}=445)$ \\
\hline F Statistic & $17.480^{* * *}(\mathrm{df}=4 ; 452)$ & $2.243^{*}(\mathrm{df}=3 ; 453)$ & $117.840^{* *+}(\mathrm{df}=3 ; 453)$ & $72.821^{* * *}(\mathrm{df}=11 ; 445)$ \\
\hline
\end{tabular}




\begin{tabular}{|c|c|c|c|c|}
\hline & \multicolumn{4}{|c|}{ Dependent variable: } \\
\hline & \multicolumn{4}{|c|}{ FDI (Logged) } \\
\hline & (1) & $(2)$ & (3) & (4) \\
\hline Law Enforcement & $\begin{array}{c}0.003 \\
(0.003)\end{array}$ & & & $\begin{array}{c}0.001 \\
(0.002)\end{array}$ \\
\hline External Supervision & $\begin{array}{l}-0.002 \\
(0.004)\end{array}$ & & & $\begin{array}{l}-0.003 \\
(0.004)\end{array}$ \\
\hline Public Satisfaction & $\begin{array}{l}0.0005 \\
(0.005)\end{array}$ & $\begin{array}{c}-0.022^{* *} \\
(0.009)\end{array}$ & & $\begin{array}{c}-0.021^{* *} \\
(0.009)\end{array}$ \\
\hline Policy Transparency & $\begin{array}{c}-0.006^{* *} \\
(0.003)\end{array}$ & & $\begin{array}{c}0.104^{* *} \\
(0.042)\end{array}$ & $\begin{array}{c}0.092^{* *} \\
(0.041)\end{array}$ \\
\hline GDP Growth Rate (Nominal) & & $\begin{array}{c}-0.183^{* * *} \\
(0.057)\end{array}$ & & $\begin{array}{c}-0.182^{* * *} \\
(0.054)\end{array}$ \\
\hline Public Satisfaction * GDP Growth Rate & & $\begin{array}{c}0.003^{* * *} \\
(0.001)\end{array}$ & & $\begin{array}{c}0.003^{* * *} \\
(0.001)\end{array}$ \\
\hline GDP Per Capita (Logged) & & & $\begin{array}{c}1.872^{+* *} \\
(0.389)\end{array}$ & $\begin{array}{c}1.630^{* * *} \\
(0.388)\end{array}$ \\
\hline Population (Logged) & & & & $\begin{array}{c}1.280^{* * *} \\
(0.386)\end{array}$ \\
\hline Airport & & & & $\begin{array}{c}0.363 \\
(0.303)\end{array}$ \\
\hline High-speed Railway & & & & $\begin{array}{c}0.019 \\
(0.117)\end{array}$ \\
\hline Policy Transparency * GDP Per Capita & & & $\begin{array}{c}-0.010^{* * *} \\
(0.004)\end{array}$ & $\begin{array}{c}-0.009^{* *} \\
(0.004)\end{array}$ \\
\hline Observations & 457 & 457 & 457 & 457 \\
\hline $\mathrm{R}^{2}$ & 0.014 & 0.037 & 0.090 & 0.158 \\
\hline F Statistic & $1.270(\mathrm{df}=4 ; 355)$ & $4.498^{* * *}(\mathrm{df}=3 ; 356)$ & $11.736^{* * *}(\mathrm{df}=3 ; 356)$ & $5.939^{* * *}(\mathrm{df}=11 ; 348)$ \\
\hline
\end{tabular}

From Table 8 and 9, I can learn that first, the four indicators of the rule of law have different influences on FDI attraction. After controlling time and locations, policy transparency is the most significant factor. Second, when the interaction terms, which I have proven significant previously, are added, I can find that they are significant. However, such significance is observed only in two-way fixed-effect models. Such a comparison means that for OLS estimations, I may fail to control the time-varying effects and location differences, and these issues may hinder us from drawing correct estimation results.

Finally, public satisfaction has a similar influence trend with the overall rule of law, negative for slowly-developing cities, and positive for fast-growing regions. However, the policy supervision tends to impact the cities with lower GDP per capita level positively and influence the FDI of higher prosperity negatively. These results reveal the patterns in which the sub-indicators of the rule of law interact with socio-economic settings and influence jointly on the FDI attraction.

\section{ROBUSTNESS CHECKS}


With significant conclusions presented in the previous section, several problems, including autocorrelation and multicollinearity, may twist my results. In this part, I will try to deal with the problems that either violates the Gauss-Markov (G-M) assumptions related to OLS estimations or issues that prevent the results from being robust.

From the dataset and the analysis presented above, I learn that the $4^{\text {th }}$ and $5^{\text {th }} \mathrm{G}-\mathrm{M}$ assumptions and the $6^{\text {th }}$ classical linear assumption may be violated. G-M assumption 4 requires zero-condition mean, which can be proven in the Residual vs. Fitted plot in Figure 7. I can observe that the residual values are generally symmetrical about the $\mathrm{x}$-axis, which indicates that for every specific $\mathrm{x}$, the mean of the unobserved factors is expected to be 0 . Thus, this assumption can be seen as not violated.

And for the classical linear assumption 6, the normality of error terms, the Q-Q plot in Figure 8 shows that the distributions of the error terms are close to normal ones, except for a few outliers. However, the outliners are rare, and the general trend indicates that the $6^{\text {th }}$ assumption for linear regression models is likely to be met.

Figure 7: Residuals Plot

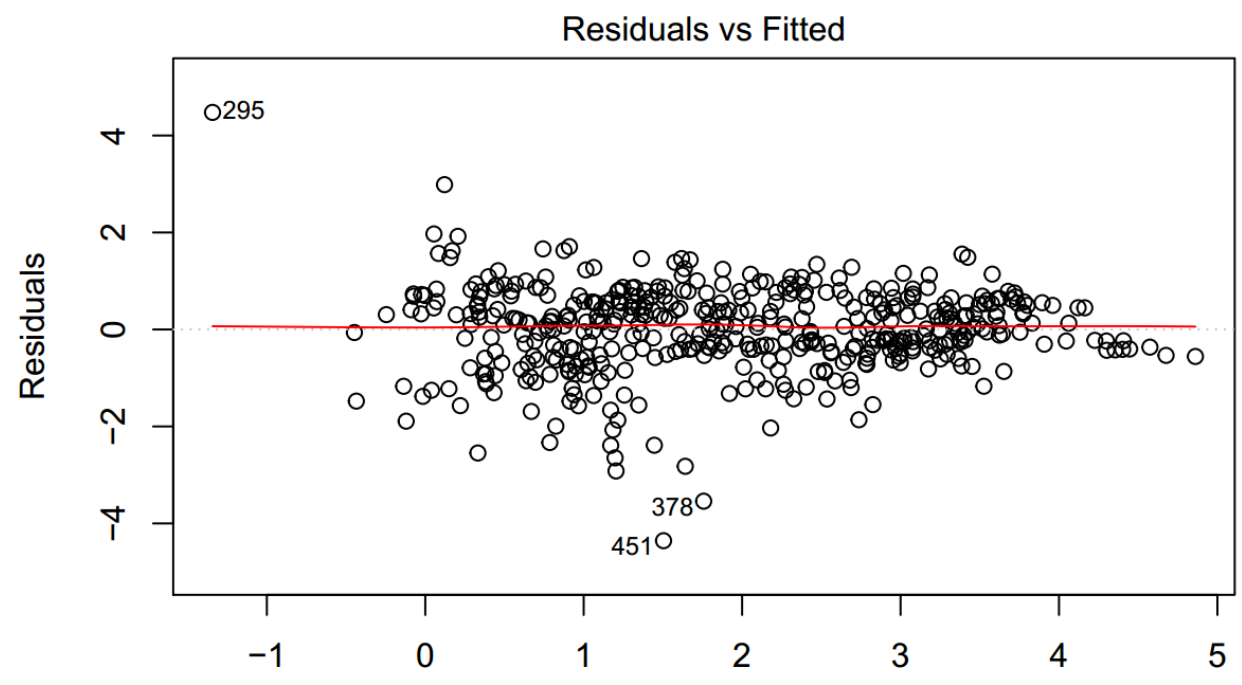

Figure 8: Q-Q Plot

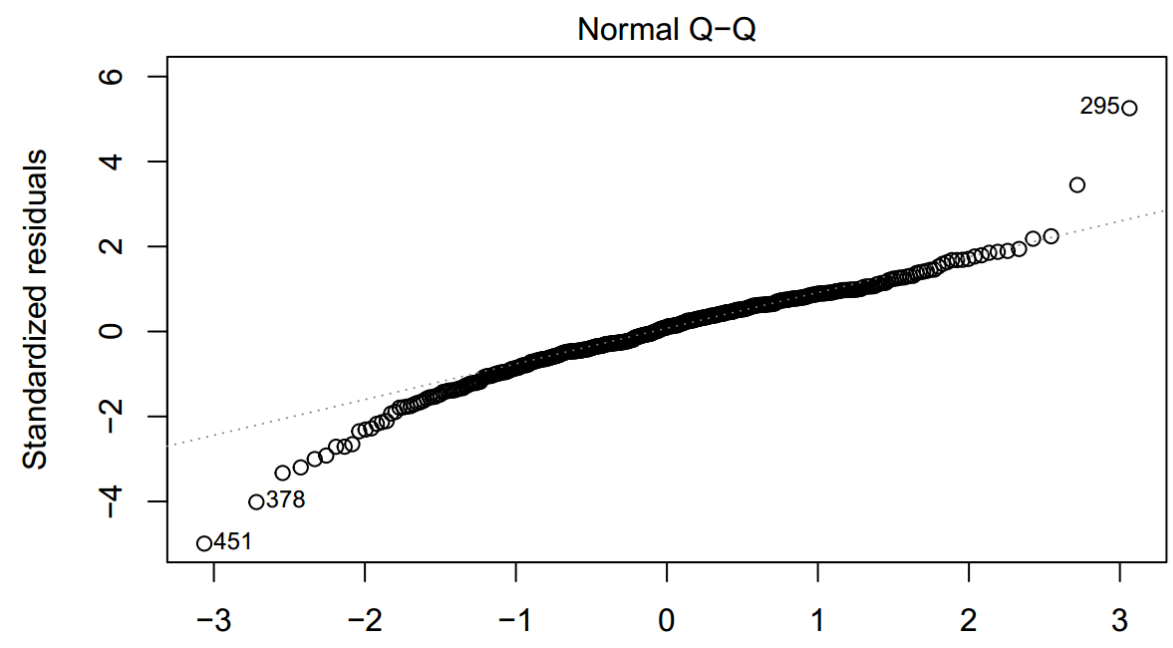


For the heteroskedasticity problem, I may draw a preliminary assumption from the Residual vs. Fitted plot in Figure 7 that, the variances of residuals are similar across different fitted values. Besides, the two-way fixed effect regressions control the effects of time and cities on residuals, and since their results conform with those from OLS regressions, I may conclude that although heteroskedasticity has some impact on my dataset, the main significant results are robust.

In addition, the concern of multicollinearity, which means two or more independent variables are highly correlated, is a common problem in multivariate regressions, especially when macro-level economic indicators are included. Therefore, I conduct a VIF test for the fifth model in Table 6, which is the OLS regression with full variables. And the results show that the maximum value of the VIF test is 1.57729 , indicating that the multicollinearity problem is not so serious in this essay.

Furthermore, the problem of missing values may be severe when researchers are collecting observational datasets like mine. I have addressed that in this research, the information of some cities is not revealed to the public. In Table 10, I can observe that the unavailable entries are more common in cities that are less developed. And from Figure 9, I learn that the percentage of missing values is not so high, and concentrated in the FDI column due to a lack of information. Thus, I assume that the missing values in my dataset are caused by observed indicators, leading to a missing at random (MAR) situation. Therefore, it's reasonable for us to impute the unavailable values, and produce unbiased estimation of regression results with these imputations.

Table 10: Lines with Missing Values

\begin{tabular}{rllrrr}
\hline & city & province & year & rank & FDI \\
\hline 1 & lasa & xicang & 2014.00 & 97.00 & \\
2 & kashi & xinjiang & 2014.00 & 99.00 & \\
3 & lasa & xicang & 2015.00 & 99.00 & \\
4 & kashi & xinjiang & 2015.00 & 100.00 & \\
5 & lanzhou & gansu & 2016.00 & 80.00 & \\
6 & fushun & liaoning & 2016.00 & 94.00 & \\
7 & xining & qinghai & 2016.00 & 41.00 & \\
8 & lasa & xicang & 2016.00 & 98.00 & \\
9 & kashi & xinjiang & 2016.00 & 100.00 & \\
10 & lanzhou & gansu & 2017.00 & 87.00 & \\
11 & haikou & hainan & 2017.00 & 51.00 & \\
12 & zhoukou & henan & 2017.00 & 94.00 & \\
13 & anshan & liaoning & 2017.00 & 78.00 & \\
14 & fushun & liaoning & 2017.00 & 81.00 & \\
15 & huhehaote & neimenggu & 2017.00 & 74.00 & \\
16 & lasa & xicang & 2017.00 & 100.00 & \\
17 & kashi & xinjiang & 2017.00 & 99.00 & \\
18 & qujing & yunnan & 2017.00 & 92.00 & \\
19 & zhoukou & henan & 2018.00 & 80.00 & \\
20 & anshan & liaoning & 2018.00 & 84.00 & \\
21 & baotou & neimenggu & 2018.00 & 92.00 & \\
22 & lasa & xicang & 2018.00 & 99.00 & \\
23 & kashi & xinjiang & 2018.00 & 100.00 & \\
\hline
\end{tabular}

Figure 9: Missing Value Distributions 

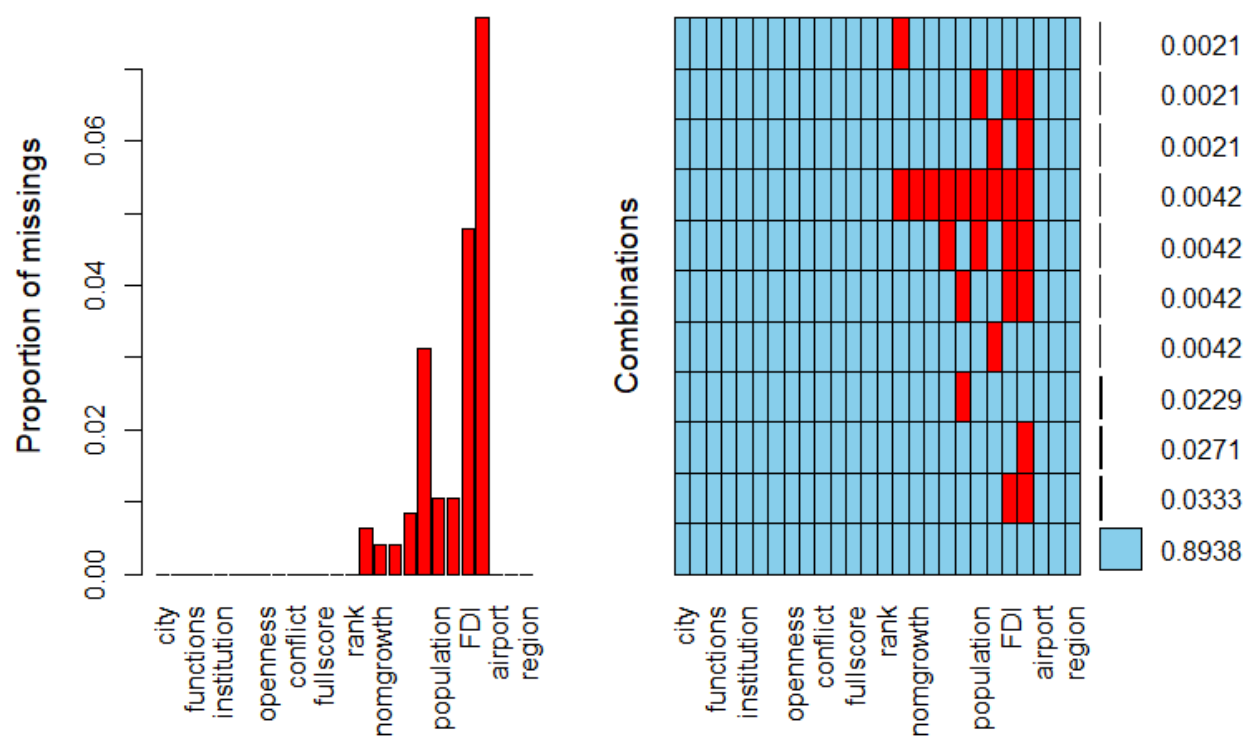

Based on this assumption, I utilize the k-nearest-neighbor $(\mathrm{KNN})$ method to impute. This method uses the values, "closest" to the missing ones, to simulate the unavailable entries (here the distances with missing cases are defined by estimating the similarity of other available variables). In this case, such imputations are produced without repetitive regressions, and thus, I can calculate the models in the Results section again, based on the imputed dataset, to check their robustness.

After the imputation is completed, the regression results change accordingly. They are presented in Table 11, and I can find that the results don't change much; in fact, some coefficients turn out to be more significant. This consistency demonstrates that my analysis, even with some MAR missing values, are still robust after these values are imputed. 
Table 11: FDI on Rule of Law and Control Variables (Robust Test) (Two-way Fixed Effect)

\begin{tabular}{|c|c|c|}
\hline & \multicolumn{2}{|c|}{ Dependent variable: } \\
\hline & \multicolumn{2}{|c|}{ FDI (Logged) } \\
\hline & $(1)$ & $(2)$ \\
\hline Overall Rule of Law & $\begin{array}{c}-0.168^{* * *} \\
(0.060)\end{array}$ & \\
\hline Law Enforcement & & $\begin{array}{c}0.002 \\
(0.002)\end{array}$ \\
\hline External Supervision & & $\begin{array}{c}-0.005 \\
(0.004)\end{array}$ \\
\hline Public Satisfaction & & $\begin{array}{c}-0.026^{* * * *} \\
(0.008)\end{array}$ \\
\hline GDP Growth Rate (Nominal) & $\begin{array}{l}-0.009 \\
(0.005)\end{array}$ & $\begin{array}{c}-0.204^{* * * *} \\
(0.052)\end{array}$ \\
\hline Policy Transparency & & $\begin{array}{c}0.083^{* *} \\
(0.040)\end{array}$ \\
\hline GDP Per Capita (Logged) & $\begin{array}{c}0.941^{* * *} \\
(0.197)\end{array}$ & $\begin{array}{c}1.625^{* * *} \\
(0.369)\end{array}$ \\
\hline Population (Logged) & $\begin{array}{c}0.522^{* * *} \\
(0.196)\end{array}$ & $\begin{array}{c}0.526^{* * *} \\
(0.195)\end{array}$ \\
\hline Airport & $\begin{array}{c}0.341 \\
(0.310)\end{array}$ & $\begin{array}{c}0.366 \\
(0.310)\end{array}$ \\
\hline High-speed Railway Station & $\begin{array}{c}0.140 \\
(0.115)\end{array}$ & $\begin{array}{c}0.116 \\
(0.116)\end{array}$ \\
\hline Rule of Law * GDP Growth Rate & $\begin{array}{c}0.018^{\text {*** }} \\
(0.005)\end{array}$ & \\
\hline Public Satisfaction * GDP Growth Rate & & $\begin{array}{c}0.003^{* * *} \\
(0.001)\end{array}$ \\
\hline Policy Transparency * GDP Per Capita & & $\begin{array}{c}-0.008^{* * *} \\
(0.004)\end{array}$ \\
\hline Observations & 480 & 480 \\
\hline $\mathrm{R}^{2}$ & 0.133 & 0.152 \\
\hline Adjusted $\mathrm{R}^{2}$ & -0.113 & -0.101 \\
\hline F Statistic & $8.190^{* * *}(\mathrm{df}=7 ; 373)$ & $6.000^{* * *}(\mathrm{df}=11 ; 369)$ \\
\hline
\end{tabular}

Additionally, I conduct a Durbin-Watson test to evaluate the autocorrelation effect of panel data. The D-W value is 1.8712 , and the p-value is 0.09445 . Thus, I cannot reject the null hypothesis that errors are serially uncorrelated, and the alternative that they follow a first-order autoregressive process cannot be accepted, reducing the possibility of the nonindependence of errors. The Augmented Dickey-Fuller test returns a result of -4.8625 , with a $0.01 \mathrm{p}$-value. I can thus reject the null hypothesis of the ADF test and argue that my dataset is stationary.

Finally, a MAR missing values problem can be seen as a specific type of omitted variable $(\mathrm{OV})$ bias. However, other kinds of OV bias are also common in political science research, and I have tried to settle some of them. For instance, the infrastructure is a significant variable that may positively impact on both the independent and dependent variables. However, local investment statistics are unavailable to the public, and if I fail to 
contain them in regressions, the coefficient of the independent variable may be overstated. Therefore, I use the high-speed railway station and the airports as proxy variables of infrastructure levels. Though proxy indicators are not the best choice, what I select are commonly treated as the reflection of a city's performance in infrastructure constructions.

\section{CONCLUSIONS AND DISCUSSION}

In conclusion, my study proves that both the overall rule of law and the nomocracy indicators are significantly influencing the cities' attraction to the FDI, while some aspects of the rule of law (i.e., public satisfaction and policy transparency) have more significant impacts than other components. Nevertheless, the marginal effects of these variables rely on the prosperity and the economic growth rate of the regions. I find that fast-developing cities can work hard on improving the rule of law, which will further increase their appeal for foreign investors. However, a higher nomocracy in slowly growing cities may hinder the FDI inflows. Therefore, approaches including tax reliefs and favorable policies may better serve the policy-makers for the goal of increasing the FDI in these regions.

It's true that the essay has some problems that affect my analysis. I have managed to deal with some of them. For instance, I have discussed the missing value problem and the proxy variables of municipal infrastructure, and thus part of the omitted variable bias is prevented. However, other types of OV bias may also impact the robustness of my conclusions. For instance, the characteristics of the cities' leadership are also indicators that may influence both the independent variable and the FDI inflows. Not controlling them, therefore, can lead to an OV bias. For instance, if the education level is positively impacting both the rule of law level and the FDI inflows, then I would expect an overestimation of the rule of law's influence on FDI attraction.

But pitifully, this is not a problem that I can settle immediately. Although I have made some arguments above, previous theories have raised a few hypotheses on how leadership influences the local rule of law constructions. Thus, it's unlikely for us to decide whether I am making reasonable hypothesis and the question that which features of leaders should be collected remains unsettled. Therefore, I am unable to test the significance of these unobserved variables and to examine the influences of this OV bias.

In addition, it is true that my study doesn't provide possible explanations on why the growth rate and GDP per capita influence the marginal effects of the rule of law on FDI inflows differently. The primary reason is that I lack pre-existing literature on that topic, and few current theories can tell a story similar to the cases I mention in this paper. However, this paper establishes an original municipal dataset on the rule of law and the FDI attraction in China. Also, this essay is among the very few papers that demonstrate the significance of the interactions between nomocracy and economic indicators.

Thus, I have laid a solid foundation in the studies of the rule of law's impact on FDI inflows, and future studies, based on the data and conclusions in my analysis, are expected to investigate the mechanisms in which the rule of law promotes or hinders FDI attraction in certain types of cities in China. 


\section{BIBLIOGRAPHY}

Aboal, D., Noya, N., \& Rius, A. (2014). Contract Enforcement and Investment: A Systematic Review of the Evidence. World Development, 64, 322-338.

Acemoglu, D., \& Johnson, S. (2005). Unbundling Institutions. Journal of Political Economy, 113(5), 949-995.

Acemoglu, D., Johnson, S., \& Robinson, J. A. (2001). The Colonial Origins of Comparative Development: An Empirical Investigation. American Economic Review, 91(5), 13691401.

Agrast, M. D., Botero, J. C., Martinez, J., Ponce, A., \& Pratt, C. (2013). WJP Rule of Law Index 2012-2013. Retrieved from Washington, D.C.

Annan, K. (2004). The Rule of Law and Transitional Justice in Conflict and Post-Conflict Societies.

Bai, C.-E., Lu, J., \& Tao, Z. (2006). Property Rights Protection and Access to Bank Loans. Economics of Transition, 14(4), 611-628. doi:doi:10.1111/j.1468-0351.2006.00269.x

Barro, R. J. (1996). Determinants of Economic Growth: A Cross-Country Empirical Study. Barzel, Y. (1997). Economic Analysis of Property Rights. Cambridge: Cambridge university press.

Bellamy, R. P. (2005). The Rule of Law and the Separation of Powers: Ashgate/Dartmouth. Bodansky, D. (2008). The Concept of Legitimacy in International Law, Berlin, Heidelberg. Campos, N. F., \& Nugent, J. B. (1999). Development Performance and the Institutions of Governance: Evidence from East Asia and Latin America. World Development, 27(3), 439-452. doi:https://doi.org/10.1016/S0305-750X(98)00149-1

Carothers, T. (1998). Rule of Law Revival. Foreign Affairs, 77, 95-106.

Carothers, T. (2006). The Problem of Knowledge. In Promoting the Rule of Law Abroad (pp. 15-28): Carnegie Endowment for International Peace.

Chesterman, S. (2008). An International Rule of Law? The American Journal of Comparative Law, 56(2), 331-361.

Clark, I. (2005). Legitimacy in International Society: Oxford University Press on Demand.

Clark, I. (2007). International Legitimacy and World Society: Oxford University Press.

Cox, M. (2008). Security and Justice: Measuring the Development Returns. A review of knowledge.

Dam, K. W. (2006). The Law-Growth Nexus: The Rule of Law and Economic Development. Washington, D.C.: Brookings Institution Press.

Davis, D. E. (2006). Undermining the Rule of Law: Democratization and the Dark Side of Police Reform in Mexico. 48(1), 55-86. doi:doi:10.1111/j.1548-2456.2006.tb00338.x

Davis, K. E., \& Trebilcock, M. J. (2008). The Relationship Between Law and Development: Optimists Versus Skeptics. The American Journal of Comparative Law, 56(4), 895-946.

Diamant, N. J., Lubman, S. B., \& O'Brien, K. J. (2005). Engaging the Law in China: State, Society, and Possibilities for Justice: Stanford University Press.

Dunning, J. H., \& Lundan, S. M. (2008). Multinational Enterprises and the Global Economy: Edward Elgar Publishing. 
Ferejohn, J., \& Pasquino, P. (2003). Rule of Democracy and Rule of Law. In J. M. Maravall \& A. Przeworski (Eds.), Democracy and the Rule of Law (pp. 242-260). Cambridge: Cambridge University Press.

Franck, S. D. (2006). Foreign Direct Investment, Investment Treaty Arbitration, and the Rule of Law Symposium: Judicial Independence and Legal Infrastructure: Essential Partners for Economic Development. Pacific McGeorge Global Business \& Development Law Journal, 19, 337-374.

Fu, D. (2017). Disguised Collective Action in China. Comparative Political Studies, 50(4), 499-527. doi:10.1177/0010414015626437

Fu, H., \& Cullen, R. (2008). Weiquan (Rights Protection) Lawyering in an Authoritarian State: Building a Culture of Public-Interest Lawyering. The China Journal (59), 111127.

Ginsburg, T. (2000). Does Law Matter for Economic Development? Evidence from East Asia. In: JSTOR.

Ginsburg, T. \& Moustafa, T. (2008). Rule by Law: The Politics of Courts in Authoritarian Regimes. Cambridge: Cambridge University Press.

Hadfield, G. K., \& Weingast, B. R. (2014). Microfoundations of the Rule of Law. 17(1), 21 42. doi:10.1146/annurev-polisci-100711-135226

Haggard, S., MacIntyre, A., \& Tiede, L. (2008). The Rule of Law and Economic Development. Annual Review of Political Science, 11(1), 205-234. doi:10.1146/annurev.polisci.10.081205.100244

Haggard, S., \& Tiede, L. (2011). The Rule of Law and Economic Growth: Where are We? World Development, 39(5), 673-685. doi:10.1016/j.worlddev.2010.10.007

Hechter, M. (2009). Legitimacy in the Modern World. In: Sage Publications Sage CA: Los Angeles, CA.

Helmke, G., \& Rosenbluth, F. (2009). Regimes and the Rule of Law: Judicial Independence in Comparative Perspective. 12(1), 345-366. doi:10.1146/annurev.polisci.12.040907.121521

Hewko, J. (2002). Foreign Direct Investment in Transitional Economies: Does the Rule of Law Matter. East European Constitutional Review, 11(4), 71-79.

Hoff, K., \& Stiglitz, J. E. (2002). After the Big Bang? Obstacles To the Emergence of the Rule of Law in Post-Communist Societies.

Jensen, N. M. (2003). Democratic Governance and Multinational Corporations: Political Regimes and Inflows of Foreign Direct Investment. International Organization, 57(03). doi: $10.1017 / \mathrm{s} 0020818303573040$

Kaufmann, D., Kraay, A., \& Zoido-Lobaton, P. (1999). Governance Matters. Retrieved from Washington, DC:

Keith, R. C. (1994). China's Struggle for the Rule of Law. Houndmills, Basingstoke, Hampshire; New York, N.Y.: Macmillan; St. Martin's Press.

King, G., Pan, J., \& Roberts, M. E. (2014). Reverse-engineering censorship in China: Randomized experimentation and participant observation. Science, 345(6199), 1251722. 
Levi, M., Sacks, A., \& Tyler, T. (2009). Conceptualizing legitimacy, measuring legitimating beliefs. American Behavioral Scientist, 53(3), 354-375.

Li, J. S. (2003). Relation-based versus Rule-based Governance: an Explanation of the East Asian Miracle and Asian Crisis. Review of International Economics, 11(4), 651-673. doi:doi:10.1111/1467-9396.00409

Lubman, S. B. (1999). Bird in a Cage: Legal Reform in China After Mao: Stanford University Press.

Malesky, E., \& London, J. (2014). The Political Economy of Development in China and Vietnam. Annual Review of Political Science, 17, 395-419.

Maravall, J. M., \& Przeworski, A. (2003). Democracy and the Rule of Law. Cambridge: Cambridge University Press.

Massoud, M. F. (2013). Law's Fragile State: Colonial, Authoritarian, and Humanitarian Legacies in Sudan: Cambridge University Press.

Merry, S. E. (2016). The Rule of Law and Authoritarian Rule: Legal Politics in Sudan. Law \& Social Inquiry, 41(2), 465-470.

Moustafa, T. (2008). The Struggle for Constitutional Power: Law, Politics, and Economic Development in Egypt. In T. Ginsburg \& T. Moustafa (Eds.), Rule by Law: The Politics of Courts in Authoritarian Regimes. Cambridge: Cambridge University Press.

Ndao, M., Hima, A., Rabiou, A., \& Lama, J. (2004). World Development Report 2005: A Better Investment Climate for Everyone. The World Bank.

North, D. C. (1981). Structure and Change in Economic History: Norton.

North, D. C., \& Thomas, R. P. (1973). The Rise of the Western World: A New Economic History: Cambridge University Press.

Nwabuzor, A. (2005). Corruption and Development: New Initiatives in Economic Openness and Strengthened Rule of Law. Journal of Business Ethics, 59, 121-138. doi:10.1007/s10551-005-3402-3

O'Donnell, G. A. (1998). Polyarchies and the (Un) Rule of Law in Latin America: Instituto Juan March de Estudios e Investigaciones.

O'Donnell, G. A. (2004). Why the Rule of Law Matters. Journal of Democracy, 15(4), 32-46. doi:10.1353/jod.2004.0076

Ohnesorge, J. K. M. (2007). The Rule of Law. 3(1), 99-114. doi:10.1146/annurev.lawsocsci.3.011207.080748

Peerenboom, R. (2002). China's Long March Toward Rule of Law: Cambridge University Press.

Pournarakis, M., \& Varsakelis, N. (2004). Institutions, Internationalization and FDI: the Case of Economies in Transition. Transnational Corporations, 13, 77-94.

Prados de la Escosura, L., \& Sanz-Villarroya, I. (2009). Contract Enforcement, Capital Accumulation, and Argentina's Long-run Decline. Cliometrica, 3(1), 1-26. doi:10.1007/s11698-008-0026-8

Przeworski, A., Limongi, F., \& Giner, S. (1995). Political Regimes and Economic Growth. In Democracy and Development (pp. 3-27): Springer. 
Rajah, J. (2012). Authoritarian Rule of Law: Legislation, Discourse and Legitimacy in Singapore: Cambridge University Press.

Raz, J. (1997). The Rule of Law and Its Virtue. Law Quarterly Review, 93, 195-211.

Rigobon, R., \& Rodrik, D. (2005). Rule of Law, Democracy, Openness, and Income. The Economics of Transition, 13(3), 533-564. doi: 10.1111/j.1468-0351.2005.00226.x

Rodrik, D., Subramanian, A., \& Trebbi, F. (2004). Institutions Rule: the Primacy of Institutions over Geography and Integration in Economic Development. Journal of Economic Growth, 9(2), 131-165.

Rosenfeld, M. (2000). The Rule of Law and the Legitimacy of Constitutional Democracy. Southern California Law Review, 74, 1307-1352.

Roseveare, C. (2013). The Rule of Law and International Development. Retrieved from London, UK.:

Santos, A. (2006). The World Bank's Uses of the "Rule of Law" Promise in Economic Development. In A. Santos \& D. M. Trubek (Eds.), The New Law and Economic Development: A Critical Appraisal (pp. 253-300). Cambridge: Cambridge University Press.

Scalia, A. (1989). The Rule of Law as a Law of Rules. The University of Chicago Law Review, 56(4), 1175-1188. doi:10.2307/1599672

Schlaeppi, E., \& McCabe, C. (2008). Rule of Law, Justice Sector Reforms and Development Cooperation. In: Concept Paper, Bern: Swiss Federal Department of Foreign Affairs.

Stern, R. E. (2014). The Political Logic of China's New Environmental Courts. The China Journal (72), 53-74.

Stockmann, D., \& Gallagher, M. E. (2011). Remote Control: How the Media Sustain Authoritarian Rule in China. Comparative Political Studies, 44(4), 436-467.

Svolik, M. W. (2012). The Politics of Authoritarian Rule: Cambridge University Press.

Tamanaha, B. Z. (2004). On the Rule of Law: History, Politics, Theory. Cambridge: Cambridge University Press.

Trebilcock, M. J., \& Daniels, R. J. (2009). Rule of Law Reform and Development: Charting the Fragile Path of Progress: Edward Elgar Publishing.

Tyler, T. R. (2001). A Psychological Perspective on the Legitimacy of Institutions and Authorities. In J. T. Jost \& B. Major (Eds.), The Psychology of Legitimacy: Emerging Perspectives on Ideology, Justice, Intergroup Relations (pp. 416-436). Cambridge: Cambridge University Press.

Wang, Y. (2014). Tying the Autocrat's Hands. Cambridge: Cambridge University Press. Whiting, S. H. (2017). Authoritarian "Rule of Law" and Regime Legitimacy. Comparative Political Studies, 50(14), 1907-1940. doi:10.1177/0010414016688008

Wilson, S. (2014). A Review of Authoritarian Rule of Law: Legislation, Discourse and Legitimacy in Singapore by Jothie Rajah. Indiana Journal of Global Legal Studies, 21(1), 297-301.

Xinhua News Agency (2015). The Central Committee of the CPC and the State Council issued the "Outline of the Implementation of Constructing a Rule of Law Government (2015-2020)". Retrieved from www.gov.cn/xinwen/2015-12/28/content_5028323.htm. 